ADALAH : Buletin Hukum \&

Keadilan

Buletin Hukum \& Keadilan

@adalahuinjkt

\title{
Pola Pikir Birokrat Pengabdi
}

Husniyah* $^{*}$

Dalam rangka mewujudkan citacita bangsa yang tercantum dalam pembukaan Undang-Undang Dasar Negara Republik Indonesia Tahun 1945, perlu dibangun aparatur sipil negara yang memiliki integritas, profesionalitas, komitmen yang tinggi serta mampu menyelenggarakan pelayanan publik yang berkualitas bagi masyarakat.

Reformasi birokrasi pada hakikatnya adalah perubahan pola pikir (mindset) terhadap aparatur negara. Oleh karena itu, kesiapan untuk perubahan tersebut harus dilakukan secara masif, karena gerakan perubahan tersebut merupakan pondasi strategis dalam keberhasilan reformasi birokrasi di Indonesia.

Pegawai Negeri Sipil (PNS) yang saat ini disebut Aparatur Sipil Negara (ASN) merupakan sebuah pilihan hidup yang tidak hanya menarik sebagai profesi, tetapi juga menyimpan berbagai macam permasalahan. Terlebih jika birokrat tersebut tidak memiliki integritas yang tinggi. Paradigma para birokrat masih cenderung bermakna feodal yaitu " pejabat harus dilayani" atau "birokrasi menguasai."

Dewasa ini perubahan perilaku ASN belum tampak menunjukan perubahan ke arah yang lebih baik. Semakin banyak ditemukan birokrat yang menjadi tersangka korupsi, kurang memahami tugas dan tanggung jawabnya, dan mem-

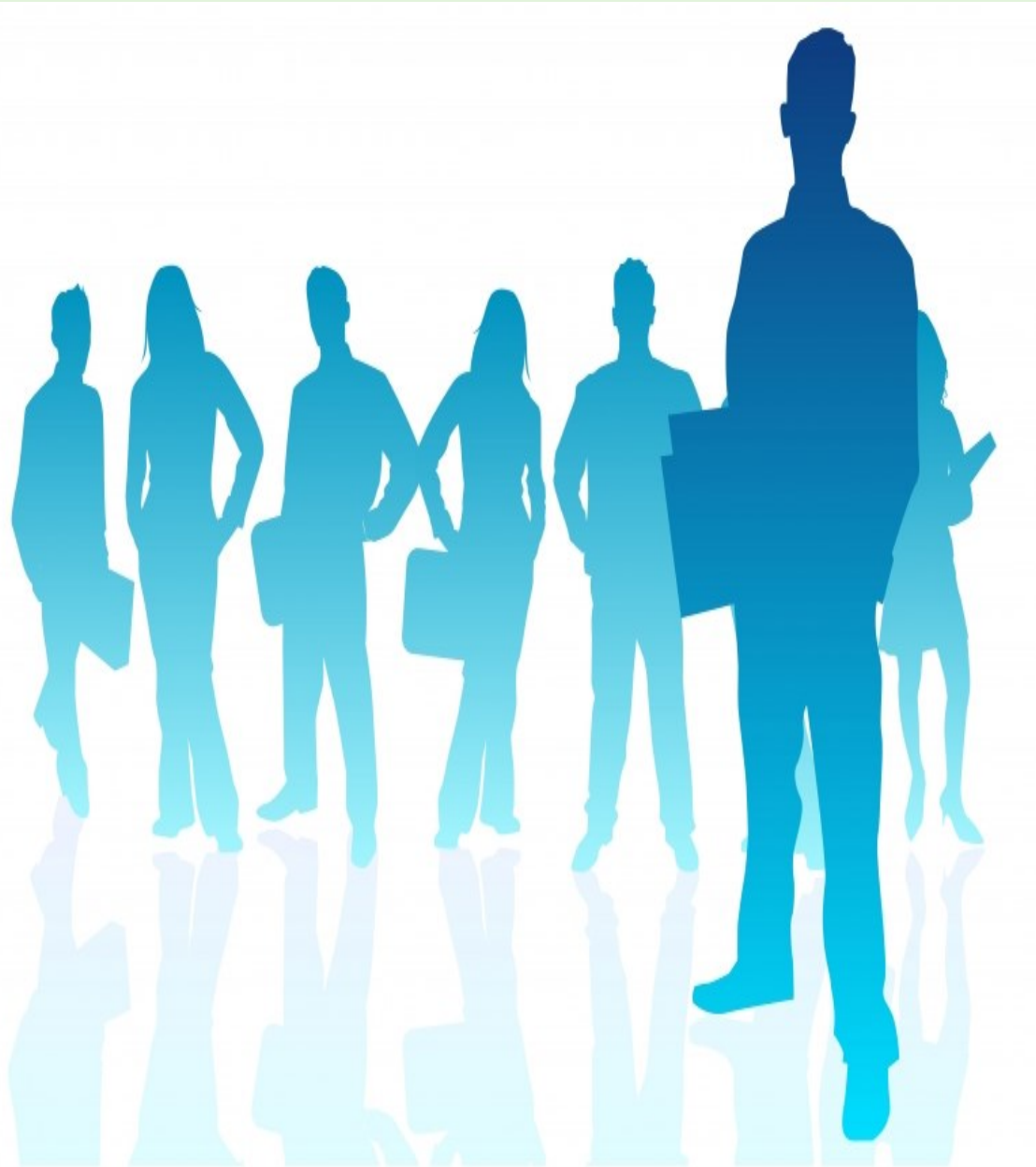

berikan pelayanan yang lamban serta malas-malasan terhadap masyarakat. Jelas sama sekali tidak nampak sisi kedaulatan masyarakat dalam menerima hak nya.

Indonesia sebagai negara hukum telah menempatkan landasan yuridis bagi warga negaranya dalam menciptakan kedaulatan rakyat, salah satunya dalam pelaksanaan pelayanan publik. Dalam ketentuan Pasal 1 ayat (2) UUD 1945, "Kedaulatan berada di tangan rakyat dan dilaksanakan menurut Undang-Undang Dasar." Pemahaman tentang rakyat dalam kedaulatan rakyat berarti kekuasaan tertinggi ada pada rakyat, dan menempatkan kekuasaan tertinggi ada pada rakyat. Oleh karena rakyat berdaulat atau berkuasa, maka segala aturan dan kekuasaan yang dijalankan oleh negara tidak boleh bertentangan dengan kehendak rakyat (Sodikin, 2014: 107). Tentunya, kinerja ASN yang "abal-abal" 
tersebut sama sekali bukan merupakan kehendak rakyat.

Sejatinya, demokrasi pada perjalanannya mengajarkan kepada para birokrat bagaimana memberikan pelayanan terbaik kepada pemilik kedaulatan. Penerima mandat tidak boleh berperilaku di atas pemegang mandat sejati, yaitu rakyat. Paradigma "pejabat harus dilayani" harus diubah "ameliorative" menjadi "abdi masyarakat" yang sebenar-benarnya.

Inilah poros nilai yang harus dipegang teguh dalam menata reformasi birokrasi. Dan inilah pengabdian untuk melayani itu. Abdi masyarakat harus diartikan setulusnya dan diejawantahkan ke dalam konstruksi pelayanan kepada masyarakat atau yang lebih dikenal dengan terminologi "pelayanan publik."

Ada beberapa aspek yang dapat diimplementasikan dalam pelayanan publik yang baik, yaitu; Pertama, aspek regulasi. Pada aspek ini desain regulasi diwujudkan dalam konstruksi atau mindset dengan mengeliminasi kekakuan bentuk-bentuk produk kebijakan hukum yang selama ini cenderung pasif terhadap aspek kesejahteraan. Kedua, aspek IT. Pada aspek ini formula administrative reform mendapatkan fungsi analisis. Artinya, kepuasan pelayanan mampu didesain dengan manfaat yang dihadirkan oleh IT itu sendiri. Ketiga, aspek sumber daya manusia dan kontrol masyarakat. Aspek ini merupakan aspek terpenting dalam mengoptimalkan SDM aparatur birokrasi yang memang tidak bisa diselesaikan dalam waktu cepat dan harus dilakukan secara gradual termasuk dilakukan juga konsep "resolusi mental."

Selanjutnya kontrol masyarakat juga menjadi bagian penting untuk tujuan perubahan kinerja sebagai ukuran dari konstruksi reformasi, maupun dalam pebuatan kebijakan ataupun Undang-Undang karena kontrol masyarakat bersifat independen dan masyarakat juga merupakan objek pelayanan yang tentu paham terhadap apa mereka butuhkan. Menurut Agus Riwanto, dengan adanya ruang untuk berpartisipasi akan semakin mendorong daya kritis masyarakat dalam me- nyoroti proses dan substansi sebuah peraturan yang sedang dibahas di DPR. Logikanya, dengan semakin terbuka kesempatan berpartisipasi, masyarakat akan semakin tahu seberapa jauh substansi sebuah RUU akan berdampak pada kehidupan mereka (Riwanto, 2016: 280).

Keterlibatan masyarakat juga merupakan perwujudan dari demokrasi deliberatif. Dengan demikian, yang terpenting adalah bahwa pelayanan publik harus bermuara pada kepuasan masyarakat dan berdampak pada kesejahteraan rakyat. Siapapun pemimpinnya, apa pun inovasinya, seberapa besar andilnya, kesejahteraan adalah Key Performance Index (KPI) yang mesti diukur dengan besaran yang representatif. Inilah perlambang besar pelayan dengan nurani kinerja tinggi sebagai pengabdi yang bekerja sepenuh hati.

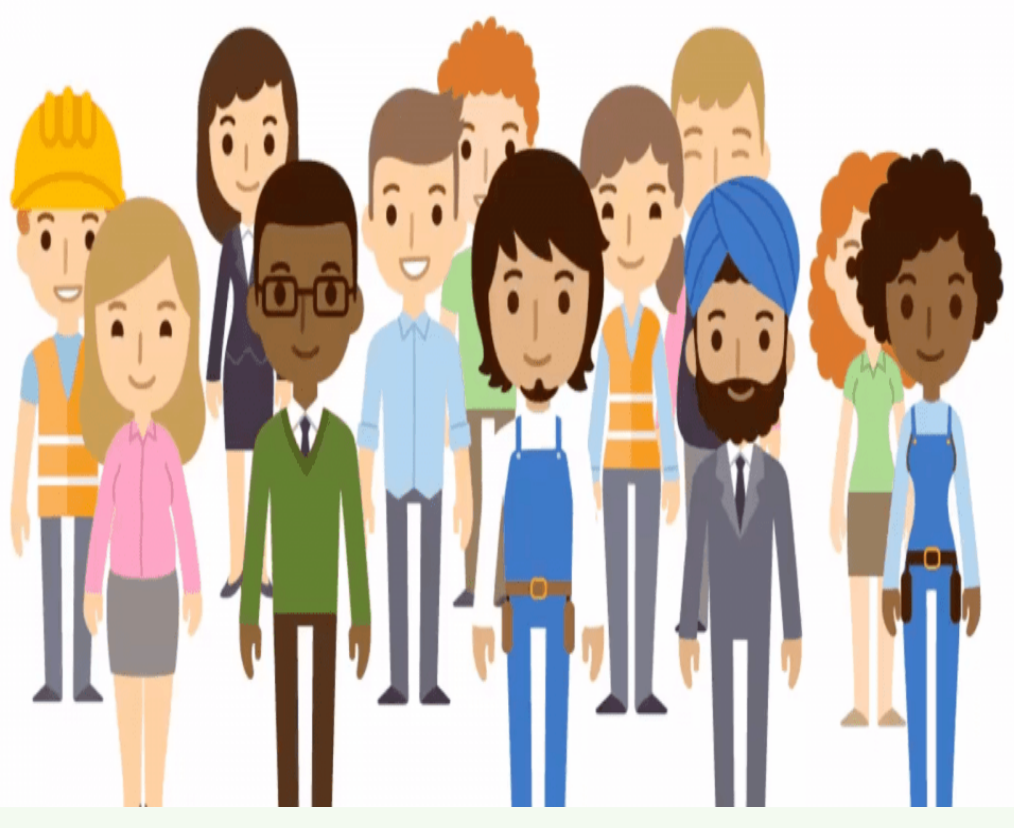

Daftar Pustaka :

* Penulis adalah mahasiswi Hukum Tata Negara FSH UIN Jakarta.

Soekarwo, "Administrative Reform, Pakde Karwo: Birokrasi itu Melayani", Jakarta: Prenada Media, 2015.

Sodikin. "Kedaulatan Rakyat dan Pemilihan Kepala Daerah Dalam Konteks Undang-Undang Dasar Negara Republik Indonesia Tahun 1945." JURNAL CITA HUKUM 2, no. 1 (2014).

Riwanto, Agus. "Strategi Politik Hukum Meningkatkan Kualitas Kinerja DPR-RI dalam Produktivitas Legislasi Nasional." JURNAL CITA HUKUM 4, no 2 (2016).

'Adalah; Buletin Hukum dan Keadilan merupakan berkala ilmiah yang diterbitkan oleh Pusat Studi Konstitusi dan Legislasi Nasional (POSKO-LEGNAS), Fakultas Syariah dan Hukum UIN Syarif Hidayatullah Jakarta.

Penasehat: Prof. Dr. H. Abdul Ghani Abdullah, SH., Prof. Dr. H. A Salman Maggalatung, SH., MH. Pemimpin Redaktur: Indra Rahmatullah, Tim Redaktur: Nur Rohim Yunus, Fathuddin, Mara Sutan Rambe, Muhammad Ishar Helmi, Erwin Hikmatiar. Penyunting: Latipah, Siti Nurhalimah. Setting \& Layout: Siti Romlah 